\title{
UTILIZING SCRABBLE AS A MEDIUM TO IMPROVE STUDENTS' VOCABULARY SKILLS IN HIGH SCHOOLS
}

\author{
Irfan Hadi \\ Universitas Indraprasta PGRI, Jakarta, Indonesia \\ irfanhadi@gmail.com
}

\begin{abstract}
A good education produces satisfactory learning outcomes. Creative learning requires teachers to be able to use all available resources so that students learn optimally. One of the efforts to maximize learning at home is the use of appropriate media for the conditions and situations at school. The teachers difficulty of using suitable media is a problem, especially the teaching of English words. Students still have insufficient vocabulary mastery; as a result,innovations and effort are required in order that students can improve their learning outcomes. One of the media that can be used is scrabble. This research used classroom action research method. The class action was carried out in 2 cycles. The initial cycle began with mapping the students initial abilities and administering a test after using Scrabble. The second cycle was conducted by improving the teaching through scrabble. 21 students were involved in the classroom action research. The results showed that scrabble could improve English vocabulary learning outcomes. The average score in cycle 1 was 77.9 and in cycle 2 was 78.9. There was an increase forl point. This result was expected to be improved as the students' vocabulary increased. Teachers should be able to use various and effective media so that students would not get bored studying in class. Learning outcomes increased along with the increase in students' activities in the classroom.
\end{abstract}

Keywords: scrabble, vocabulary, SMA

\section{PENGGUNAAN MEDIA SCRABBLED UNTUK MENINGKATKAN KEMAMPUAN KOSA KATA PADA SISWA SMA}

\begin{abstract}
ABSTRAK
Pendidikan yang baik akan menghasilkan hasil belajar yang memuaskan. Pembelajaran yang kreatif membutuhkan guru yang mampu menggunakan semua sumber yang ada agar siswa belajar optimal. Salah satu upaya untuk memeakimalkan belajar di rumah adalah penggunaan media yang sesuai dengan kondisi dan situasi di sekolah. Sulitnya guru menggunakan media yang cocok menjadi permasalahan tersendiri. Terutama pengajarn oa kata dalam bahasa Inggris. Siswa minim dalam peguasaan kosa kata. Hal ini perlu inovasi dan usaha agar siswa dapat meningatkna hasil belajar mereka. Salah satu media yang dapat digunakan adalah scrabbled. Penelitian ini menggunkan metode penelitian tindakan kelas. Tindakan kelas dilakukan sebanyak 2 siklus. Siklus awal dimulai dengan pemetaan kemampuan awal siswa, sekaligus diberikan test setelah penggunaan scrabbled. Siklus kedua dilakukan dengan perbaikan pengajaran scrabbled. Jumlah siswa yang ikut dalam penelitian tindakan kelas sebanyak 21 siswa Hasil penelitian menunjukkan bahwa media scrabbled dapat meningkatkan hasil belajar kosa kata bahasa Inggris.Rata -rata nilai pada siklus 1 sebesar 77.9 dan pada siklus 2 sebesar 78.9. Ada kenaikan sebesar 1 poin. Hasil ini diharapkan dapat ditingkatkan seiring meningatnya kemampuan kosa kata siswa. Para guru hendaknya dapat menggunakan media yang bervariatif dan efektif agar siswa tidak bosan belajar di kelas. Hasil belajar dapat meningkat seiring dengan peningakatan kegiatan siswa di kelas
\end{abstract}

Kata Kunci: scrabbled, kosa kata, SMA

\begin{tabular}{|c|c|c|}
\hline Submitted & Accepted & Published \\
\hline 28 Maret 2021 & 09 Agustus 2021 & 14 September 2021 \\
\hline
\end{tabular}

\begin{tabular}{|l|c|c|c|}
\hline Citation & $:$ & $\begin{array}{c}\text { Hadi, I. (2021). Utilizing Scrabble as a Medium to Improve Students” Vocabulary Skills in High Schools. Jurnal PAJAR } \\
\text { (Pendidikan dan Pengajaran), 5(5), 1170-1176. DOI : http://dx.doi.org/10.33578/pjr.v5i5.8385. }\end{array}$ \\
\hline
\end{tabular}

\section{INTRODUCTION}

Learning English must be equipped with adequate vocabulary and sentence structures. Without mastery of vocabulary students will experience difficulties in composing sentences, and at times expressing sentences. When students are able to master vocabulary, but have not mastered adequate sentence structure, students will find it difficult to assemble sentences correctly. So that the relationship between vocabulary and sentence structure is very close, 
and cannot be separated from one another. Mastery of vocabulary is one of the main requirements that determines the success of an individual to become skilled at language, the richer the individual's vocabulary is, the more likely the individual is to become skilled at language (Rahayu.S, et al: 2018)

The vocabulary ability becomes the foundation for understanding the concept of reading comprehension in English. The students' vocabulary skills can be the basis for assembling sentences correctly. In the learning process in the teacher's classroom, sometimes they have difficulty teaching vocabulary effectively. The teaching process will take a long time, if the methods used are not interesting and tedious. Students sometimes mispronounce vocabulary, this is understandable, because teaching pronunciation is also constrained by the lack of reading practice, plus low reading interest.

The teachers have used a lot of other learning tools, methods and learning resources. However, it is necessary to pay attention to the conditions and situations in the classroom, because each class and region has different characteristics. For example, learning in cities and villages, of course, is very different and can be a separate consideration, before using a tool and method in class.

Learning methods in the classroom can be an impact on the results of students' skill levels. methods that are in accordance with students' abilities will encourage student learning success, especially learning vocabulary. Giving exercises and explanations from the teacher is very important. Because students will feel confused, if students are not given examples and explanations of how to read and pronounce vocabulary.

Mastery of vocabulary is still an obstacle for class X Al Ikhlas high school students. The minimum completeness criteria are still below 75 . The average daily test score was 74 . Students are not optimally studying in class. This makes students less enthusiastic about learning. English teachers have not explored classroom learning. This is obtained after the teacher reveals the learning constraints in class.
The use of media is very necessary. The use of media can be a learning aid, so that students learn with enthusiasm in class, and can reduce boredom. Among the learning media that can be used in class is scrabbled. This media can be used and is well known as a game among students. The use of this game is very simple, students can use English and fill in the scores they get. This media can help students interact (Sunarmintyastuti, L, et al: 2020). Efforts to learn Indonesian language skills continue. One of them is by diversifying learning media in the classroom (Widiyarto.S, et al: 2017)

Based on the description above, the author will examine the use of scrabbled media to improve vocabulary skills in Al Ikhlas high school students, Bekasi city.

\section{LITERATURE REVIEW Vocabulary}

Vocabulary is the whole word that a person has, divided into active vocabulary (vocabulary used by the speaker or writer) and passive vocabulary (vocabulary that is understood by listeners and readers, but is not used alone) '. From the definitions stated above, it can be concluded that vocabulary is a collection of things language or certain language fields or the entire words owned by someone that includes active vocabulary, namely the vocabulary used as a speaker and writer and passive vocabulary that he understands when he is a listener and reader.

\section{Scrabbled}

Scrabble is a board game and word arrangement game played by 2 or 4 people who collect points based on the value of the words formed from the letters on the game board with boxes ( 15 columns and 15 rows). one side. Players take up to seven pieces of letter keeping from the bag, and try to arrange words horizontally or downwards like a crossword puzzle. The words that are made must be words that are allowed to be played based on the standard dictionary according to the language being played. The player who collects the highest points is declared the winner. The objectives of language games according to him are first to stimulate verbal interaction of learners, 
second to increase fluency and confidence, third to provide a learning context, fourth to act as a tool that can erode boredom; dane. The five act as tools for recovery, confirmation and enrichment

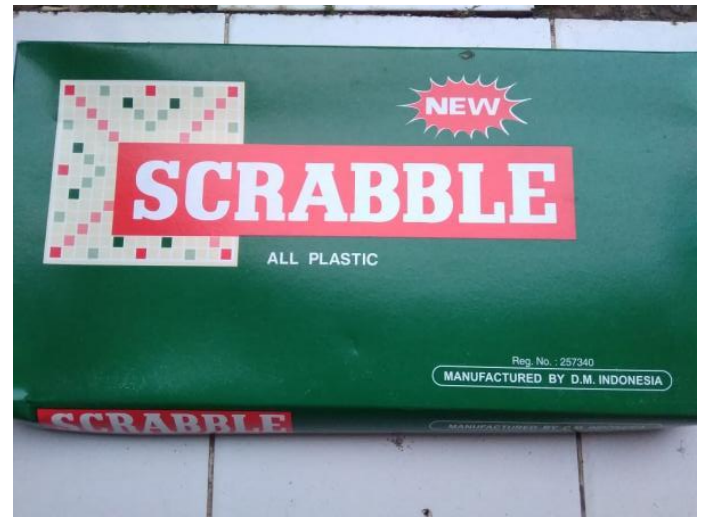

Figure 1. Scrabbled

\section{RESEARCH METHODS}

The research method used is a classroom action research method. The writers used 2 cycles. In the first cycle the writer used scrabbled media as a method of learning vocabulary. students are provided with 4 scrabbled media. Each medium used 4 students. The use begins with the teacher's explanation of how to use the media. The highest score will be the first winner. Meanwhile, students with less grades are still given appreciation for participating in class learning and games.

Methods of data collection are carried out through tests, observation and documentation. The data collection techniques used were: (a) Tests, observations, and documentation. The test method was used to obtain data about students' vocabulary before the study, during the study (cycle 1) and after the study (cycle 2) was carried out. The observations used were systematic observations, namely observations made by the observer with the basic use as an observation instrument. The instruments used in this research are: observation sheets, tests, and documentation. Observation sheets are used by researchers as a guide for making observations or observations in order to obtain accurate data in the observations. Observation sheets are also used to observe and review each class action so that the observation activity remains a part of the problem study and research objectives. The test is used to see how much the students' vocabulary mastery of the material. The test scores that have been carried out (cycles 1 and 2) are the basis for analysis to determine vocabulary mastery after learning using scrabbled. The indicator of success in this study is if the average value is at least 75.0 (KKM limit). The stages of data analysis include data categories, data validation, data interpretation, and action plans.

\section{RESULTS AND DISCUSSION}

After learning in class, by using scrabbled, the students were first enthusiastic about seeing the game. Some students have already known and used the game at home, and some of them have never used it, even though they have heard. Some are happy because they will play while learning.

Before using this tool, the writer explains the flow of the game, how to achieve the highest score and upholds honesty and cooperation with other students. This game is given approximately 45 minutes. Students who can achieve the highest score will be awarded points. In the initial cycle the teacher demonstrated this tool, as an exercise to sharpen vocabulary. The teacher gives examples of the game slowly, then gives some practice questions. For example, students have got 4 vocabulary words that are on the scrabbled board, so students are required to make simple sentences using the 4 words. For example, the student has 
made the word "well", then the student continues the work written in the exercise book, with such sentences. "I am Very well thank you" and so on. It was recorded that of the 23 students who attended the class as many as 20 students, the researcher recapitulated the results of the initial cycle tests, after being given the exercises using scrabbled as follows:

Table 1. The Table The Score of Cyce 1

\begin{tabular}{cc}
\hline Nama Siswa & Nilai \\
\hline A & 73 \\
MS & 81 \\
HR & 78 \\
SC & 75 \\
RK & 74 \\
DG & 80 \\
JH & 80 \\
SR & 78 \\
BU & 77 \\
LK & 67 \\
KU & 88 \\
DJ & 89 \\
KM & 87 \\
FA & 81 \\
ZA & 76 \\
MG & 78 \\
VR & 78 \\
DM & 75 \\
KL & 66 \\
Rata-rata & 77.9 \\
& \\
\hline
\end{tabular}

Sorrce : Research 2021

In the data above the average has reached 77.9 above the KKM of 75. However, there are still 3 students who score below 75 . This should be appreciated because the students' grades have increased, even though they are still below the
KKM. Those students, wanting to try again, get better grades. Even though in the initial cycle the students were not ready to use scrabbled, they said they wanted to try again, so that their grades could increase.

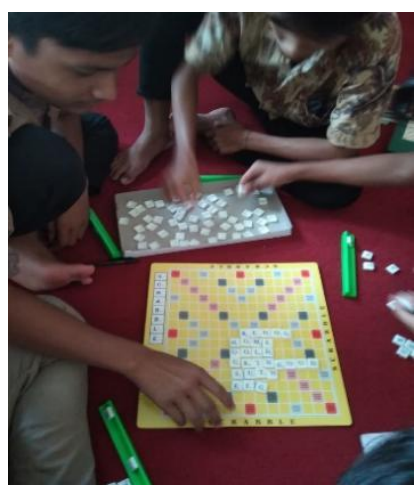

Figure 2. Scrabbled Game and The Students 
After the students are given the opportunity to try and practice, the students are required to compete. With other students, at the same time practicing good vocabulary skills. In the span of 1 hour, students are still allowed to open the dictionary, to add memory and how to pronounce. When they find a letter, they are also required to read / pronounce the word.

This is done so that students get used to reading words correctly, besides that they are required to make one sentence, based on the words they get. The use of simple sentences follows a sentence pattern that meets the requirements, such as a sentence that must have a subject pattern, a predicate / working word, an object, a time or place record, and so on.

The habit of writing in books based on the acquired vocabulary can be done at home as an additional task. The students wrote neatly and clearly.

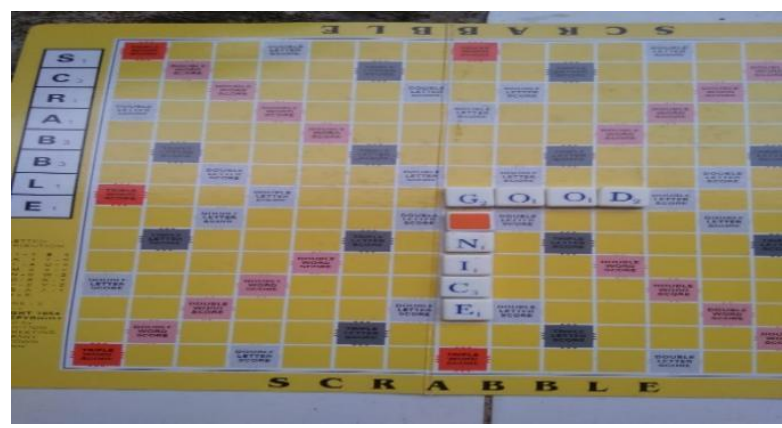

Figure 3. Word at The Board

In Figure 2, it can be seen that students get the word "good" so that students can write / make sentences such as "Good man always comes on time in the class"
In the second cycle, the writer explained how to use scrabbled and how to determine the score. After that the author, assisted by the teacher, gave a multiple choice test of 25 questions

Table 2. Table of Cycle 2 Score

\begin{tabular}{cc} 
Student's Name & Score \\
\hline A & 83 \\
MS & 90 \\
HR & 75 \\
SC & 75 \\
RK & 75 \\
DG & 81 \\
JH & 81 \\
SR & 79 \\
BU & 77 \\
LK & 67 \\
KU & 88 \\
DJ & 88 \\
KM & 87 \\
FA & 80 \\
ZA & 75 \\
\hline
\end{tabular}




\begin{tabular}{cc}
\hline MG & 77 \\
VR & 77 \\
DM & 75 \\
KL & 70 \\
Rata-rata & 78.9 \\
\hline
\end{tabular}

In table 2, it can be seen that the average is 78.9 , this value is up from cycle 1 . In general, the students seemed enthusiastic and happy to be able to learn vocabulary in class by using crabbled. The increase from cycles 1 and 2 is 1 . Although not much, the authors assess that psychologically the students already have good confidence in pronouncing vocabulary. In the pre-cycle the average English learning was 74, after the learning treatment using scrambled was done the average was 77.9, and in the second cycle it was 78.9.

In the pre-cycle, it can be understood that the average value is not as big as the value in cycles 1 and 2 . These results can provide a conclusion that learning using scrabbled is very beneficial for improving English learning outcomes, especially vocabulary learning. This is in accordance with the results of research by Kusumawati, N. (2019) which states that learning by using scrambled students is more enthusiastic and motivated.

\section{CONCLUSIONS AND RECOMMENDATION}

Based on the description above, it can be concluded that scrabble media can improve vocabulary learning outcomes at Alikhlas High School, Bekasi city. Increments by 1 point from cycle 1 to cycle 2 ,. Meanwhile, the value from pre cycle to cycle 1 increased by 3.9 points. Vocabulary learning in English is a learning that emphasizes practice. so that with the use of scrabbled it can be assured that children will be more active and practice better.

The writer suggests that teachers can use more effective media other than scrabble. This needs to be done so that students do not get bored. The results of this research can be used as a basis for developing further research. Consistent coaching and practice can change vocabulary learning outcomes for the better. The teachers are expected to be able to modify other games, so that they can provide innovation and creativity to English learning in the future.

\section{REFERENCES}

Ati, A. P., \& Widiyarto, S. Literasi Bahasa Dalam Meningkatkan Minat Baca Dan Menulis Pada Siswa Smp Kota Bekasi. Basastra, 9(1), 105-113.

Febriyanti, R. H., Hadi, I., \& Saputri, N. L. (2018, September). Penerapan penggunaan eclectic method dalam pengajaran bahasa Inggris pada guru SDIT dan SMPIT. In Seminar Nasional dan Diskusi Panel Multidisiplin Hasil Penelitian dan Pengabdian Kepada Masyarakat 2018 (Vol. 1, No. 1).

Pramesti, U. D. (2015). Peningkatan penguasaan kosakata bahasa Indonesia dalam keterampilan membaca melalui teka-teki silang (Penelitian tindakan di kelas VI SDN Surakarta 2, Kecamatan Suranenggala, Kabupaten Cirebon, Jawa Barat). Puitika, 11(1), 82-93.

Rahayu, S., Rasmitadila, R., \& Makarim, H. (2018). Penggunan Media Kartu Kata Bergambar Dalam Meningkatkan Kosakata Siswa Down Syndrome. Didaktika Tauhidi: Jurnal Pendidikan Guru Sekolah Dasar, 5(2), 94-105.

Sunarmintyastuti, L., Suprapto, H. A., Wulansari, L., Sandiar, L., \& Sartono, L. N. (2020). Pembelajaran Cooperative Learning Berbantuan Media Scrabble dalam Pembelajaran IPS pada Siswa SMP. JURNAL ILMIAH WAHANA PENDIDIKAN, 6(4), 636-640.

Supandi, A., Sahrazad, S., Wibowo, A. N., \& Widiyarto, S. (2020). Analisis kompetensi guru: pembelajaran revolusi industri 4.0. Prosiding Samasta. Widiyarto, S., 
Wulansari, L., \& Hasanusi, F. S. (2020). Pelatihan "english communicative" guna mempersiapkan sdm berkualitas dan "competitive". Intervensi Komunitas, 1(2), 125-131.

Saputri, N. L., \& Hadi, I. I. (2021). An Analysis Of Idiom Expressions In Novel "Mary Poppins" By Pl Travers. Jurnal Lentera Pendidikan Pusat Penelitian Lppm Um Metro, 6(1), 14-30.

Hadi, I. (2021). An Error Analysis of Active and Passive Voice Towards English Text of University Students in South Jakarta. Jurnal Ilmiah Wahana Pendidikan, 7(2), 9-16.

Juita, H. R., \& Widiyarto, S. (2019, March). The Effectiveness of Cooperative Learning Methods: A case study of writing learning at Junior High School. In Second Conference on Language, Literature, Education, and Culture (ICOLLITE 2018) (pp. 266-268). Atlantis Press.

Kusumawati, N. (2019). Pengaruh Model Pembelajaran Scramble Dengan Media Question Card Terhadap Hasil Belajar IPA Siswa Kelas IV SDN Kertosari II Kabupaten Madiun. Ibriez: Jurnal Kependidikan Dasar Islam Berbasis Sains, 4(1), 87-100.

Widiyarto, S., Damayanti, N., \& Ati, A. P. (2017). Pemakaian Media Scrabbled Dalam Meningkatkan Kemampuan Kosakata Kalimat Dan Keterampilan Menulis Narasi. GERVASI: Jurnal Pengabdian kepada Masyarakat, 1(1), 71-77.

Wibowo, A. N., Supandi, A., Andri, A., \& Widiyarto, S. (2020). Pemanfaatan Pembelajaran ICT Dalam Optimalisasi Proses Belajar Mengajar Guru SMP. Jurnal Pengabdian UntukMu NegeRI, 4(2), 228-230.

Widiyarto, S., Wulansari, L., \& Hasanusi, F. S. (2020). Pelatihan "english communicative" guna mempersiapkan sdm berkualitas dan "competitive". Intervensi Komunitas, 1(2), 125-131. 